\title{
E-Report: Holistic Assessment System In Elementary School
}

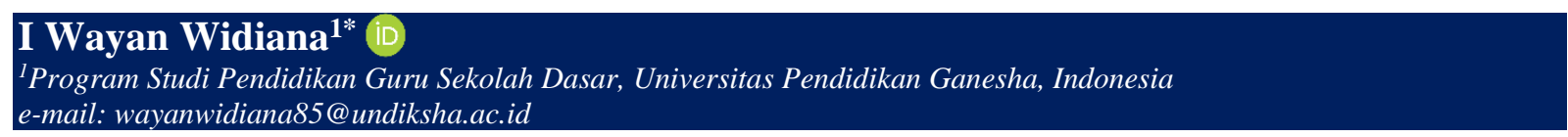

\section{A R T I C L E I N F O}

Article history:

Received April 20, 2021

Revised April 22, 2021

Accepted June 12, 2021

Available online August 25, 2021

Kata Kunci:

Sistem Penilaian, Satuan

Pendidikan, Rapor Siswa

Keywords:

Assessment System, Education

Unit, Student Report Card

DOI: https://dx.doi.org/

10.23887/jet.v5i3.39017

\begin{abstract}
A B S T RAK
Pembelajaran yang baik tidak hanya didukung oleh perencanaan dan proses pembelajaran yang baik, tetapi juga didukung oleh penilaian pencapaian kompetensi siswa. Penelitian ini bertujuan untuk mengembangkan sistem penilaian hasil belajar berbasis satuan pendidikan (laporan siswa) di sekolah dasar. Penelitian ini merupakan penelitian pengembangan dengan menggunakan model Development and Diffusion (R-D-D). Data dalam penelitian ini dikumpulkan melalui wawancara, observasi, angket, studi dokumentasi, FGD, dan uji coba produk. Analisis data menggunakan pendekatan kualitatif. Hasil penelitian menunjukkan bahwa persentase tingkat ketercapaian sistem penilaian hasil belajar berbasis satuan adalah 97,3\% sehingga masuk dalam kualifikasi Sangat Baik dengan skala tingkat ketercapaian 5 pada tabel konversi. Berdasarkan hal tersebut, dapat disimpulkan bahwa sistem Student Report (SR) layak digunakan sebagai sistem penilaian hasil belajar berbasis satuan pendidikan di sekolah dasar. Implikasi penelitian ini yaitu guru dapat menggunakan E-raport yang dikembangkan sebagai sistem penilaian hasil belajar berbasis satuan pendidikan di sekolah dasar.
\end{abstract}

\section{A B S T R A C T}

A good learning is supported by not only good planning and learning processes, but it is also supported by an assessment of students' competencies achievement. This study aims to develop a learning outcome assessment system based on educational units (students' reports) in elementary schools. This is development research using Development and Diffusion (R-D-D) model. The data in this study were collected through interviews, observations, questionnaires, documentation studies, FGDs, and product trials. The data were analyzed using a qualitative approach. The results showed that the percentage level of achievement of the unit-based learning outcomes assessment system was $97.3 \%$ so which fell into Very Good qualification with the achievement level scale of 5 in the conversion table. Based on this, it can be concluded that the Student Report (SR) system is appropriate to be used as an education unit-based learning outcome assessment system in elementary school. This research implies that teachers can use the developed E-report as a learning outcomes assessment system based on education units in elementary schools.

This is an open access article under the $\underline{C C B Y-S A}$ license.

Copyright (C) 2021 by Author. Published by Universitas Pendidikan Ganesha.

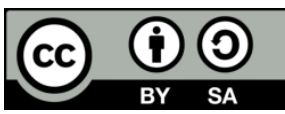

\section{INTRODUCTION}

Assessment is one of the methods used in determining the success of the learning process, and it is known that learning and assessment cannot be separated (McGarr \& Gallchóir, 2021; Saito et al., 2021; Wright et al., 2010). The existence of an assessment process provides an opportunity to find out how the learning conditions are taking place (All et al., 2021; Alruwais et al., 2018). The assessment carried out by the teacher has an impact on students because it provides feedback on what students have learned and understood (Granberg et al., 2021). Currently, the assessment process carried out is the provision of reports given to students in the middle of the semester and at the end of the semester, both manual and excel report cards. The nature of the report cards given at this time is still static, meaning that it is only the teachers who have the opportunity to process the data (P. A. D. Pangastuti \& Priantinah, 2019; Wijasty et al., 2019). Another weakness is that report cards cannot assess the overall activity being carried out. Moreover, students should be given their assessment result as soon as possible since it is needed to improve themselves in learning and if the assessment is given at the end of the semester, it would be in vain since those result are only seen as a collection of the overall values obtained, not to improve them in learning during that semester (Brookhart et al., 2016; Layuk et al., 2014). In other words, the current report card is not quite effective because it does not describe the real condition of students as a whole. This condition will greatly affect the improvement of the learning process that takes place and their motivation in learning (Astalini et al., 2019; Klapp, 2015). Further, currently, both students and 
teachers are not satisfied with the results of the assessment because they have lost the principles of the assessment (Hansen, 2020).

The learning assessment being carried out will allow students to improve and develop their abilities in the learning process (Segers et al., 2018; Xiao \& Yang, 2019). The assessment process should be done every day so that it shows the changes and development made by students during their learning process. A summative assessment demonstrates a transparent assessment principle (Bdiwi et al., 2019; Danniels et al., 2020). An assessment shows the students' abilities, knowledge, attitudes, and skills after the learning process (Schildkamp et al., 2020; Zhang et al., 2020). However, assessment does not only stop in the process of assessing, but students' development must also be reported both by students and by the teachers themselves to parents and school principals (Szanto, 2020; Wegmann \& Smith, 2019). The results of the assessment should show a more dynamic way in which the reports given will change according to the situation and condition of the students. This, of course, will show that the students have different abilities in the fields according to their interests and talents. Thus, a good, complete, continuous and gradual assessment process will have a good impact on students as subjects and objects of education. But in reality, the assessment being carried out were not in accordance with what was needed by the students and the current condition of the students. Thus, the students are not able to make any improvement neither to correct their mistakes to avoid learning failures. Also, the reporting process used by teachers is not all in digital form. This is because not all teachers possess the ability to operate computers or there are not many e-report cards have been developed (Buchori et al., 2017; Danniels et al., 2020).

Based on the results of preliminary observations in Cluster II, Buleleng District, it was found that in its implementation, process assessment activities (formative) and learning outcomes (summative) based on the 2013 Curriculum at the elementary level, some educators (teachers) felt that assessment was a burden, especially in terms of performing techniques and procedures, processing and reporting the results of the assessment. The procedures and assessment techniques carried out by the teacher are still routine and not yet referring to the nature and principles of assessment. Teachers have not used various assessment procedures and techniques. The teacher's assessment is still limited to assessing the knowledge aspect. In general, teachers still do not understand the learning assessment methodology, including assessment techniques and tools, good assessment criteria, form and types of instruments, scoring and remedial and enrichment implementation programs. An indication of the teacher's ability in preparing assessment procedures can be seen from the frequency of using various forms of assessment instruments. On the other hand, the type of assessment carried out by the teacher is in accordance with the demands of the curriculum, namely through tests assessment. The forms of tests used so far are essay for daily quizzes and tests, and multiple-choices tests for midterm and end-of-semester tests. Until now, research on school-based assessments, especially those related to graduation systems and a comprehensive and sustainable assessment system, has not been widely conducted. The focus of developing assessments at the primary school level is still carried out partially, which is limited to assessment instruments, such as the development of authentic assessments, development of scientific attitude assessment instruments, and development of Higher Order Thinking Skill (HOTS) assessment instruments (Hanifah, 2019; Suryani, 2016; Widiana, 2016). All of this research did not lead to the development of an educational unit-based assessment system. Thus, the current assessment process is still not in accordance with existing needs. Therefore, it is necessary to develop an effective assessment system in accordance with technological developments, namely the online report card system.

Several previous studies have found that the e-report is efficient, effective, and it eases the teacher's duties in assessing (Juliantri et al., 2017; Pangastuti \& Priantinah, 2019). However, the existing e-report cards have not fully fulfilled the need for students' evaluation results. To overcome the shortage of existing e-report cards, the Students' Report Card System was developed. This report card was developed by carrying out the assessment principles. The principles of assessment are continuous, accountable, transparent, comparative, and systematic (Nurhayati, 2016). In students' report card, a complete information about students will be developed, not just their learning outcomes. Learning outcomes including knowledge, attitudes and skills obtained after participating in learning (Dewi et al., 2014; Rambe, 2018; Umami, 2018). In this students' report card, assessment will be added related to the interests and talents of students. What distinguishes it from other report card systems is that the teacher will report all of students' learning outcomes every day after the learning process is done so that it shows how the they progress each day. These results also show the interests and talents of students so that parents and teachers are able to direct the students according to their interests and talent. Thus, this study aims to develop a comprehensive and sustainable learning outcome assessment system. The assessment system was developed based on the educational unit and named Students' Report.

\section{METHOD}

This is a development research (Research \& Development). Development research is a systematic study consisting of the process of designing, developing, and evaluating. This type of research aims to create and 
develop products in the form of tools used to support the learning process (Pranatawijaya et al., 2019). This study uses a Research, Development, and Diffusion (R-D-D) development model. In this study, the stages being carried out were only the development stage, the diffusion stage could not be done because of the occurrence of COVID-19. First, in the research stage, a literature review was conducted by examining various theories related to the assessment process, forms of assessment, student graduation criteria, and assessment standard; thus, the components of the assessment and indicators can be determined. Furthermore, observations at elementary schools in Buleleng were conducted, as well as interviews with school principals, vice principals in curriculum, quality assurance units or academic development teams, teachers in the field of study and counseling guidance, and a school supervisor. Interviews and observations were carried out to observe firsthand the various efforts of schools to improve the quality of the assessment process based on educational assessment standards.

Second, the model development stage begins with formulating the components of the evaluation model to reveal the problems experienced in learning. Furthermore, from these components a grid, points, and scoring rubric were arranged for evaluation instruments which included teacher's self-evaluation, peer evaluation, and student evaluation. Instruments that have been prepared in the previous stage and revised at the testing and evaluation stage were then put together in the form of booklets and / or computer-based software so that schools can easily access and use them and respondents can easily fill them out. The information provided by teachers and students' respondents through filling in computer-based evaluation instruments can be read directly by the principal or the authorized person as material for supervision, feedback, and improvement or further learning enhancement. The testing and evaluation phase of the instrument aims to: (1) assess the suitability of indicators with items, (2) determine items that have good quality theoretically and empirically, (3) determine the reliability of the instrument, and (4) collect data on the strengths and weaknesses of schools in learning. The instruments developed in this study included teacher's self-evaluation, peer evaluation, and student evaluation.

There were two stages of collecting the data in this study, namely the research stage and the development stage. At the research stage, the data were collected through interviews, observations, questionnaires, and document studies. Meanwhile, at the development stage, the data were obtained through Focus Group Discussion and product testing. The obtained data in were analyzed qualitatively and quantitatively. Qualitative data analysis techniques are used to process data from observations and interviews using the interactive method of the Miles and Huberman model, which begins with the activities of writing down the results of observations and interviews, editing, classifying, reducing, and presenting.

\section{RESULT AND DISCUSSION}

\section{Result}

Based on the results of observations and interviews conducted with teachers, students, principals, and parents of students, it can be found that the types of assessment used by schools were formative and summative assessment. The assessment carried out at the primary and secondary education levels consists of an assessment by educators, an assessment by an education unit, and an assessment by the Government. Assessment of students' learning outcomes includes aspects of assessment of attitudes, knowledge, and skills. An attitude assessment is an assessment to get descriptive information about the students' behavior. Knowledge assessment is an assessment to measure students' mastery of knowledge. Skills assessment includes assessing the ability of students to apply knowledge in performing certain tasks. The procedures and assessment techniques carried out by the teacher are not yet referring to the nature and principles of assessment. Teachers did not use various assessment procedures and techniques. The teacher's assessment is still limited to assessing the knowledge aspect only. In general, teachers still did not understand the learning assessment methodology, including assessment techniques and tools, good assessment criteria, forms and types of instruments, scoring, remedial, and enrichment implementation programs. An indication of the teacher's ability in preparing assessment procedures can be seen from the frequency of using various forms of assessment instruments. On the other hand, the type of assessment carried out by the teacher is in accordance with the demands of the curriculum, namely assessment through tests. The forms of tests used so far are essay tests for daily quizzes and tests, and multiplechoice tests for midterm and end-of-semester tests. Until now, research on school-based assessments, especially those related to graduation systems and a comprehensive and sustainable assessment system, has not been widely conducted. The results of this study were the reasons for the development of the students' report card system.

The development phase of the Students' Report system begins with formulating evaluation components that come from the problems experienced by the teacher. One of the problems is that the assessment process is not yet integrated and holistic; thus, a system is needed that can help teachers to carry out the assessment process well so that the purpose of the assessment is exactly what it is intended for. The evaluation components developed are cognitive, affective, psychomotor, extracurricular assessments, interests and talents, and counseling guidance. The components that have been developed at the design stage will be developed and put together in the form of booklets or computer-based software so that schools can easily access and use them and 
respondents can easily fill them in. The information provided by teacher and student respondents through filling in computer-based evaluation instruments can be read directly by the principal or the authorized person as material for supervision, feedback, and improvement or further learning enhancement.

The development stage is the product production stage in the form of an educational unit-based learning outcome assessment system. The product development stage starts from installing Moodle on the hosting account, then managing user rights such as entering content regarding the learning outcome assessment system. In this product, there are three users, namely administrator (system manager), teachers (in charge of inputting values), and students (user of the product). The results of the development of an educational unit-based learning outcome assessment system are as follows. Users can access the learning outcome assessment system site at https://balisciences.ac.id/sr/. On the main page, there is some information about the learning category and the login menu. The main page of the learning outcome assessment system can be seen sin Figure 1 .

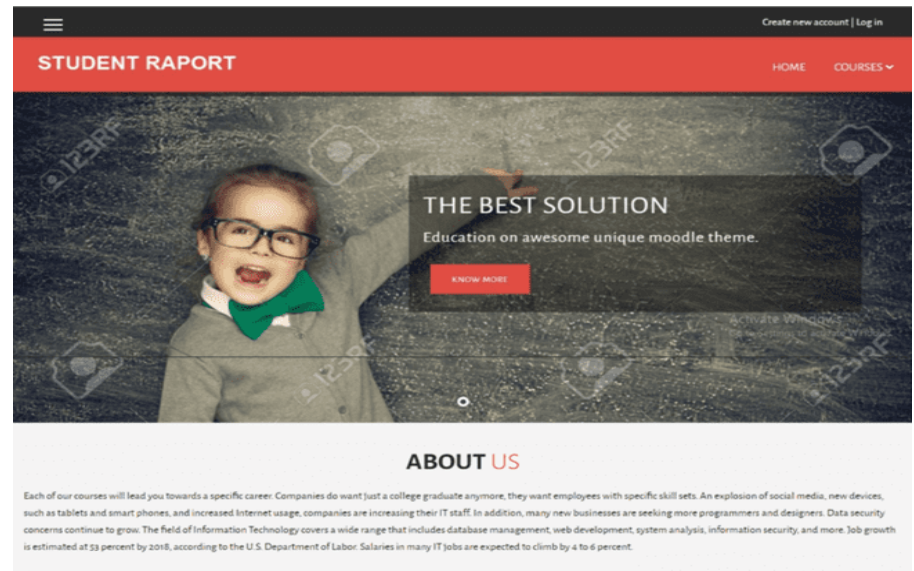

Figure 1. The display of the Education Unit-Based Learning Outcomes Assessment System Dashboard

In the main view of the learning outcome assessment system, there is a learning category available in the lower column, while the create new account and login buttons are located in the upper right corner.

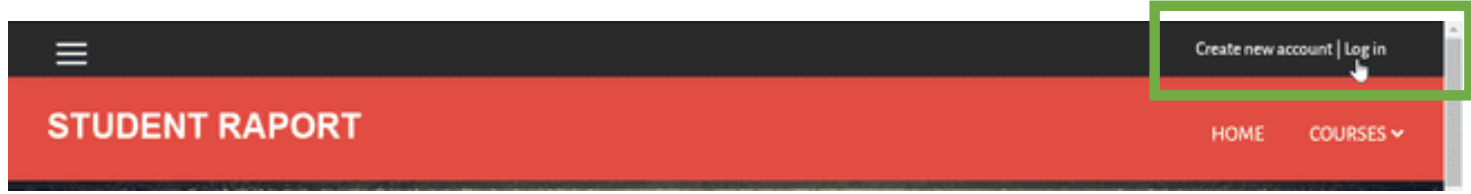

Figure 2. Create New Account and Login buttons

The login page will appear if the user has successfully logged in. This page must be filled in by each user if they want to enter the learning outcome assessment system. On the login page, the user is asked to enter a username and password. This login page can be filled by administrator, teachers, and students. Students are required to $\log$ in with the account they registered with. If the student does not have an account, the student should register or register an account first. When registering, students should put email, username, password, city name, etc. The login page display is presented in Figure 3.

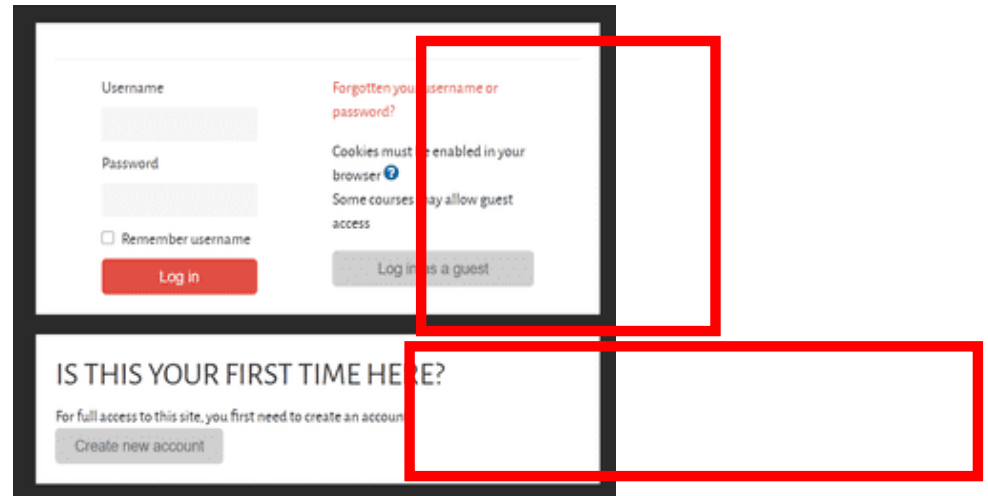

Figure 3. Login and Create New Account Display 
This page will appear as the initial display if the user successfully logs into the site. This page provides information about courses and enrolment options. In the initial screen, several menus are presented, such as the site home menu, calendar, and private files. The students' dashboard or main page after logging in successfully is presented in Figure 4 and the teacher's dashboard or main page is shown in Figure 5.

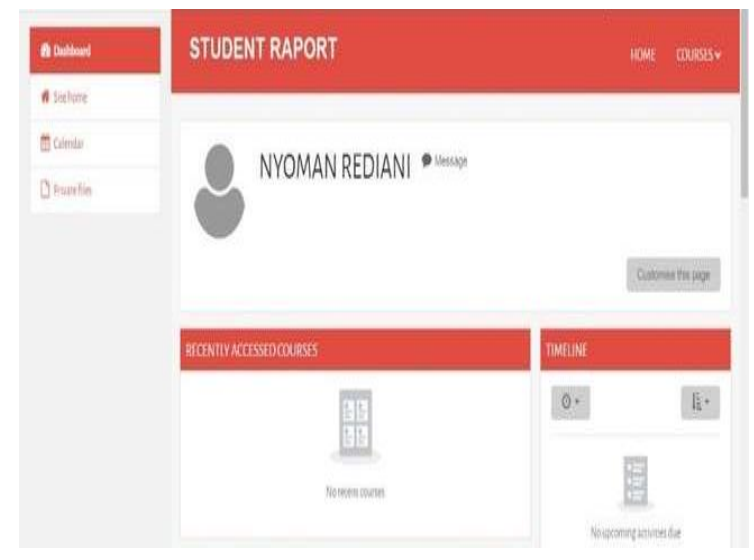

Figure 4. Student's dashboard display

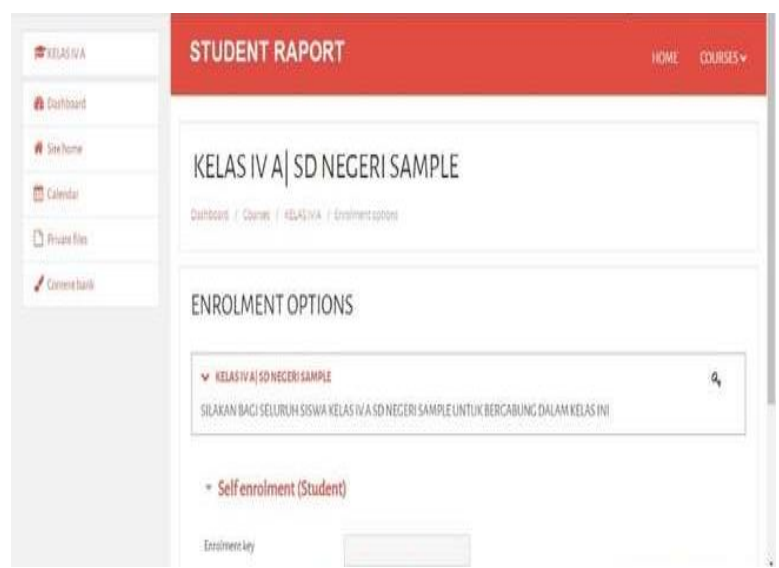

Figure 5. Teacher's dashboard display

This learning activity page is a page that contains the results of student's learning outcomes in each subject. This page is presented in a topic format. In each subject the cognitive and behavioral values are displayed. The results of the development of the learning activity results page are shown in Figure 6.

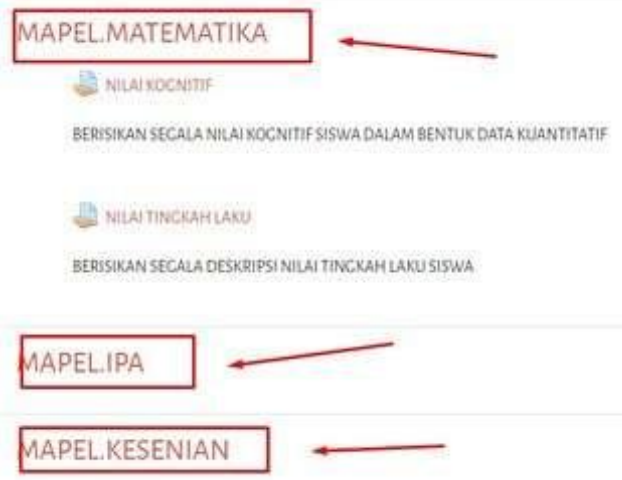

Figure 6. Score display on each subject

The final product in this development research is an educational unit-based learning outcome assessment system. Products that have been developed are judged by experts. The instrument used in this expert trial was a questionnaire. The data collection method uses a questionnaire method. Assessment is obtained through an assessment by an expert. Comments and suggestions given by experts are used as a reference in improving the system that has been developed. The following are the results of product appraisals that have been developed from experts through the questionnaire method presented. Based on the results of data analysis, the assessment given by the experts is 73 , with a maximum ideal score of 75 . It can be concluded that the developed E-report has very good qualifications. Thus, the educational unit-based learning outcome assessment system media is not necessarily revised. Comments given by media experts on the education unit-based learning outcome assessment system, namely the education unit-based learning outcome assessment system, are very innovative. Based on the results of this assessment, it can be concluded that the educational unit-based learning outcome assessment system media is appropriate and inclined to be used.

\section{Discussion}

First, a very good qualification can be achieved since the layout arrangement is concise and in accordance with the content. The layout is concise and in accordance with the content, making the display attractive (Indah Septiani et al., 2020; Khan \& Masood, 2015; Tan et al., 2021). The educational unit-based learning outcome assessment system was developed with a concise layout and in accordance with the content to ease the students to find information about their grades. An appropriate and concise layout arrangement will ease 
the users to understand the information presented on the website (Heo \& Toomey, 2020; Hignasari \& Supriadi, 2020; Mayer, 2012). The layout design in the education unit-based learning outcome assessment system consists of a header, main menu, left panel, content, right panel, and footer. Previous research also states that a simple design and supported by tools allows every user to operate the product easily and smoothly (Kamaruddin \& Haryanto, 2014). Second, very good qualifications can be achieved since of the easy access to the educational unit-based learning outcomes assessment system site. The education unit-based learning outcome assessment system is easy to be used and operated by teachers and students because this system is web-based and can be accessed anywhere and anytime (Bdiwi et al., 2019; Danniels et al., 2020). The website has become very popular because through a user-friendly website, it will ease any users from children to adults to use it with no difficulty (Kaplan et al., 2021; Tempelaar, 2019). Previous research also states that easy access to information via the internet will improve the quality of educational institutions (Koswara, 2018). Thus, it can be concluded that the ease of accessing the assessment system site will make students feel comfortable in obtaining information in the form of learning outcomes.

Third, very good qualifications can be achieved since the education unit-based learning outcome assessment system eases the teachers to input students' learning outcomes. The education unit-based learning outcome assessment system is designed practically so that teachers only have to input students' learning outcomes data (Abosalem, 2016; Wahyuningsih et al., 2016). In addition, students are also facilitated in understanding the score they get during the learning process, because the score has been equipped with a complete description; thus, they are aware of the score they deserve. Students also know the mistakes they commit during learning so that they can improve themselves in the future by not making the same mistake. The practicality of this educational unit-based learning outcome assessment system will greatly help students to find out the achievement of learning outcomes they get. Students can easily access this site anywhere and anytime.

The Students' Report Card system was developed by carrying out assessment principles. The principles of assessment are continuous, accountable, transparent, comparative, and systematic (Nurhayati, 2016; Zulfiani et al., 2020). In Students' Report Card, a complete information system about students will be developed meaning it is not only showing the students' learning outcomes. The learning outcomes, in this case, include the knowledge, attitudes and skills obtained after participating in learning (Dewi et al., 2014; Rambe, 2018; Umami, 2018). In this Students' Report Card, assessment will be added related to the interests and talents of the students. What distinguishes it from other report card systems is that the teacher will report all students' learning outcomes every day after the learning is done so that it shows the students' progress each day. Moreover, these results also show the interests and talents of students so that parents and teachers are able to direct students according to their interests and talent. Involving students in the assessment process is one good solution to developing a holistic assessment system.

\section{CONCLUSION}

Based on the results of the development carried out, the Student Report Card system is appropriate and recommended to be applied and used. The Student Report Card system was developed by carrying out assessment principles. The Student Report Card system is an education unit-based assessment system that is comprehensive and sustainable. In Students' Report Card, an information about students' score and description of why they deserve the score are shown rather than their only learning outcomes without further explanation of what they did wrong. This will lead to students' improvement in learning.

\section{REFERENCES}

Abosalem, Y. (2016). Assessment techniques and students' higher-order thinking skills. International Journal of Secondary Education, 4(1), 1-11. https://doi.org/10.11648/j.ijsedu.20160401.11.

All, A., Castellar, E. N. P., \& Looy, J. Van. (2021). Digital Game-Based Learning effectiveness assessment: Reflections on study design. Computers \& Education, 167. https://doi.org/10.1016/j.compedu.2021.104160.

Alruwais, N., Wills, G., \& Wald, M. (2018). Advantages and Challenges of Using e-Assessment. International Journal of Information and Education Technology, 8(1), 34-37. https://doi.org/10.18178/ijiet.2018.8.1.1008.

Astalini, A., Darmaji, D., Kurniawan, W., Anwar, K., \& Kurniawan, D. A. (2019). Effectivenes of Using EModule and E-Assessment. International Journal of Interactive Mobile Technologies (IJIM), 13(09), 21-39. https://doi.org/10.3991/ijim.v13i09.11016.

Bdiwi, R., de Runz, C., Faiz, S., \& Cherif, A. A. (2019). Smart learning environment: Teacher's role in assessing classroom attention. Research in Learning Technology, 27, 1-14. https://doi.org/10.25304/rlt.v27.2072.

Brookhart, S. M., Guskey, T. R., Bowers, A. J., McMillan, J. H., Smith, J. K., Smith, L. F., Stevens, M. T., \& 
Welsh, M. E. (2016). A Century of Grading Research: Meaning and Value in the Most Common Educational Measure. Review of Educational Research, 84(4). https://doi.org/10.3102/0034654316672069.

Buchori, Rahmawati, S., \& Wardani, S. (2017). The Development of A Learning Media for Visualizing the Pancasila Values Based on Information and Communication Technology. Jurnal Cakrawala Pendidikan, 36(3), 502-521. https://doi.org/10.21831/cp.v36i3.12748.

Danniels, E., Pyle, A., \& DeLuca, C. (2020). The role of technology in supporting classroom assessment in playbased kindergarten. Teaching and Teacher Education, 88. https://doi.org/10.1016/j.tate.2019.102966.

Dewi, D. A. P., Wiyasa, I. K. N., \& Ganing, N. N. (2014). Pengaruh Model Pembelajaran Circuit Learning Berbantuan Media Audiovisual Terhadap Hasil Belajar Ips Siswa Sd Negeri 1 Pejeng Tahun Pelajaran 2013/2014. Jurnal Mimbar PGSD Universitas Pendidikan Ganesha, 2(1). https://doi.org/10.23887/jjpgsd.v2i1.2226.

Granberg, C., Palm, T., \& Palmberg, B. (2021). A case study of a formative assessment practice and the effects on students' self-regulated learning. Studies in Educational Evaluation. https://doi.org/10.1016/j.stueduc.2020.100955.

Hanifah, N. (2019). Pengembangan instrumen penilaian Higher Order Thinking Skill ( HOTS ) di sekolah dasar. Current Research in Education, 1(1). https://ejournal.upi.edu/index.php/crecs/article/view/14286.

Hansen, G. (2020). Formative assessment as a collaborative act. Teachers`Intention and Students`Experience: Studies in Educational Evaluation, 66. https://doi.org/10.1016/j.stueduc.2020.100904.

Heo, M., \& Toomey, N. (2020). Learning with multimedia: The effects of gender, type of multimedia learning resources, and spatial ability. Computers and Education, 146, 103747. https://doi.org/10.1016/j.compedu.2019.103747.

Hignasari, L. V., \& Supriadi, M. (2020). Pengembangan E-Learning dengan Metode Self Assessment Untuk Meningkatkan Hasil Belajar Matematika Mahasiswa Universitas Mahendradatta. Jurnal Kependidikan, 6(2). https://doi.org/10.33394/jk.v6i2.2476.

Indah Septiani, A. nisa N. S., Septiani, I., Rejekiningsih, T., Triyanto, \& Rusnaini. (2020). Development of interactive multimedia learning courseware to strengthen students' character. European Journal of Educational Research, 9(3), 1267-1279. https://doi.org/10.12973/eu-jer.9.3.1267.

Juliantri, L., Florentinus, T. S., \& Wibawanto, H. (2017). Pengembangan e-Rapor Kurikulum 2013 Berbasis Web di SMK Negeri 1 Slawi. Innovative Journal of Curriculum and Educational Technology, 6(1). https://journal.unnes.ac.id/sju/index.php/ujet/article/view/15571.

Kamaruddin, \& Haryanto. (2014). Pengembangan Sistem Penilaian Hasil Belajar Mata Pelajaran Menganalisis Rangkaian Listrik Berbasis Computerized Adaptive Testing. Jurnal Pendidikan Vokasi, 4(1). https://doi.org/https://doi.org/10.21831/jpv.v4i1.2533.

Kaplan, L. R., Farooque, M., Sarewitz, D., \& Tomblin, D. (2021). Designing Participatory Technology Assessments: A Reflexive Method for Advancing the Public Role in Science Policy Decision-making. Technological Forecasting and Social Change, 171. https://doi.org/10.1016/j.techfore.2021.120974.

Khan, F. M. A., \& Masood, M. (2015). The Effectiveness of an Interactive Multimedia Courseware with Cooperative Mastery Approach in Enhancing Higher Order Thinking Skills in Learning Cellular Respiration. Procedia - Social and Behavioral Sciences, 176, 977-984. https://doi.org/10.1016/j.sbspro.2015.01.567.

Klapp, A. (2015). Does grading affect educational attainment? A longitudinal study. Assessment in Education: Principles, Policy and Practice, 22(3). https://doi.org/10.1080/0969594X.2014.988121.

Koswara, A. N. M. (2018). Pengaruh Kemudahaan Akses Informasi Internet Melalui Konteks Sosial Pelajar Terhadap Kecenderungan Tindakan Plagiarisme Dalam Penulisan Karya Tulis Di Kalangan Pelajar. Jurnal Masyarakat Telematika Dan Informatika, 9(1). https://doi.org/10.17933/mti.v9i1.115.

Layuk, A., Hamdani, H., \& Khairina, D. M. (2014). Sistem Informasi Pengolahan Nilai Raport Berbasis Web Sekolah Sosial Olahraga (Studi Kasus: Real Madrid Foundation Samarinda). Informatika Mulawarman, 9(3). https://doi.org/dx.doi.org/10.30872/jim.v9i3.176.

Mayer, R. E. (2012). A Cognitive Theory of Multimedia Learning. Multimedia Learning, July, 41-62. https://doi.org/10.1017/cbo9781139164603.004.

McGarr, O., \& Gallchóir, C. Ó. (2021). Examining supervising field instructors’ reporting and assessment of technology use by pre-service teachers on school placement. Computers \& Education, 146. https://doi.org/10.1016/j.compedu.2019.103753.

Nurhayati, A. (2016). Prinsip dan tujuan penilaian tindakan kelas. Jurnal Pembelajaran, 5(1). https://doi.org/10.24252/ip.v5i1.3200.

Pangastuti, A. D., \& Priantinah, D. (2019). Penerapan Sistem Informasi Raport Online. Ekuitas: Jurnal Pendidikan Ekonomi, 7(1). https://doi.org/10.23887/ekuitas.v7i1.16488.

Pangastuti, P. A. D., \& Priantinah, D. (2019). Penerapan Sistem Informasi Raport Online. Ekuitas: Jurnal 
Pendidikan Ekonomi, 7(1). https://ejournal.undiksha.ac.id/index.php/EKU/article/view/16488/10690.

Pranatawijaya, V. H., Widiatry Priskila, R., \& Putra, P. B. A. A. (2019). Pengembangan Aplikasi Kuesioner Survey Berbasis Web Menggunakan Skala Likert dan Guttman. Jurnal Sains Dan Informatika, 5(2). https://doi.org/10.34128/jsi.v5i2.185.

Rambe, K. R. N. (2018). Penerapan Strategi Index Card Match Untuk Meningkatkan Hasil Belajar Siswa Pada Mata Pelajaran Bahasa Indonesia. Jurnal Tarbiyah, 25(1), 93-124. https://doi.org/https://www.researchgate.net/deref/http\%3A\%2F\%2Fdx.doi.org\%2F10.30829\%2Ftar.v2 5i1.237.

Saito, E., Reisch, R., \& Davis-Risen, S. (2021). Utilizing a faculty-led student assessment team to evaluate international interprofessional service learning opportunities. Currents in Pharmacy Teaching and Learning, 13(9). https://doi.org/10.1016/j.cptl.2021.06.037.

Schildkamp, K., Kleij, van der, Heitink, Kippers, W. B., \& Veldkamp, B. P. (2020). Formative assessment: A systematic review of critical teacher prerequisites for classroom practice. International Journal of Educational Research. https://doi.org/10.1016/j.ijer.2020.101602.

Segers, M., Martens, R., \& Bossche, P. Van den. (2018). Understanding how a case-based assessment instrument influences student teachers' learning approaches. Teaching and Teacher Education, 24(7). https://doi.org/10.1016/j.tate.2008.02.022.

Suryani, L. (2016). Pengembangan Instrumen Penilaian Sikap Ilmiahpada Pembelajaran Dengan Model Latihan Penelitian Di Sekolah Dasar. Jurnal Pedadidaktika, https://ejournal.upi.edu/index.php/pedadidaktika/article/view/5152/0.

Szanto, B. (2020). Reading and Writing Comprehension in the Mother Tongue in the Romanian National Assessment - Objectives, Tests, Results. Technium Social Science Journal, 9. https://doi.org/10.47577/tssj.v9i1.933.

Tan, J., Yang, Z., Cheng, Y., Ye, J., Wang, B., \& Dai, Q. (2021). SRAGL-AWCL: A two-step multi-view clustering via sparse representation and adaptive weighted cooperative learning. Pattern Recognition, 117. https://doi.org/10.1016/j.patcog.2021.107987.

Tempelaar, D. (2019). Assessment \& Evaluation in Higher Education Supporting the less-adaptive student: The role of learning analytics, formative assessment and blended learning. Assessment and Evaluation in Higher Education, 45(4). https://doi.org/10.1080/02602938.2019.1677855.

Umami, M. (2018). Penilaian Autentik Pembelajaran Pendidikan Agama Islam dan Budi Pekerti dalam Kurikulum 2013. Jurnal Kependidikan, 6(2). https://doi.org/10.24090/jk.v6i2.2259.

Wahyuningsih, R., Wahyuni, S., \& Lesmono, A. D. (2016). Pengembangan Instrumen Self Assessment Berbasis Web Untuk Menilai Sikap Ilmiah pada Pembelajaran Fisika di SMA. Jurnal Pembelajaran Fisika, 4(4), 338-343. https://jurnal.unej.ac.id/index.php/JPF/article/view/3087.

Wegmann, K. M., \& Smith, B. (2019). Examining racial/ethnic disparities in school discipline in the context of student-reported behavior infractions. Children and Youth Services Review, 103. https://doi.org/10.1016/j.childyouth.2019.05.027.

Widiana, I. W. (2016). Pengembangan Assesmen Proyek dalam Pembelajaran IPA di Sekolah Dasar. Jurnal Pendidikan Indonesia, 5(2). https://doi.org/10.23887/jpi-undiksha.v5i2.8154.

Wijasty, F. A., Utami, L. D., Yunandar, R. T., \& Priyono, P. (2019). Aplikasi Sistem Informasi Raport Online (Studi Kasus: Mi Darul Muta'allimien Leuwiliang Bogor). Jurnal Ilmu Pengetahuan Dan Teknologi Komputer, 5(1). https://doi.org/10.33480/jitk.v5i1.685.

Wright, McDowell, Leese, \& McHardy, K. C. (2010). A scoping exercise of work-based learning and assessment in multidisciplinary health care in Scotland. Journal of Practice Teaching \& Learning, 10(2). https://doi.org/10.1921/ 174661110X592737.

Xiao, Y., \& Yang, M. (2019). Formative assessment and self-regulated learning: How formative assessment supports students' self-regulation in English language learning. System, 81. https://doi.org/10.1016/j.system.2019.01.004.

Zhang, J., Liao, G., \& Li, N. (2020). Combining active learning and local patch alignment for data-driven facial animation with fine-grained local detail. Neurocomputing, 39. https://doi.org/https://doi.org/10.1016/j.neucom.2019.05.102.

Zulfiani, Suwarna, I. P., \& Sumantri, M. F. (2020). Science adaptive assessment tool: Kolb's learning style profile and student's higher order thinking skill level. Jurnal Pendidikan IPA Indonesia, 9(2), 194-207. https://doi.org/10.15294/jpii.v9i2.23840. 